\title{
ISLAM DAN KEPEMIMPINAN PEREMPUAN DI RANAH POLITIK
}

\author{
Ilfi Nur Diana, M.Si
}

Dosen Fakultas Ekonomi UIN Malang

\begin{abstract}
Women's rights are mostly experiencing pressures and obstacles from all sides (groups) which are still influenced by patriarchal culture. In fact, Islam has devoted proportional rights to women such as political right, socio-ecomic rights, educational right as well as cultural right. However, their rights are sometimes socially overlooked for the religious reasons. On the contrary, that phenomenon is generated from the interpretation which is influenced by the interpreter's conditional and situational background. The most indisputable issue in recent situation is the illegibility of woman being a leader that she cannot be for any political positions. Therefore, it is necessary to do structural transformation and quality and capacity development in the same time. It is also one of effort that we need more humanistic interpretation of the Qur'an toward women.
\end{abstract}

\section{A. Pendahuluan}

Di Indonesia mayoritas penduduknya adalah muslim, namun jika diakui dari dulu hingga kini implementasi demokrasi yang sejatinya merupakan ajaran Islam, ternyata masih cukup memprihatinkan. Ini dapat dilihat dari adanya ketimpangan posisi sosial perempuan yang masih begitu kental. Misalnya, rasio kaum perempuan dan kaum laki-laki yang sangat tidak sebanding. Pada era ORBA, dari tiap delapan anggota DPR hanya ada satu perempuan, di DPA hanya ada satu perempuan dan 24 laki-laki, di lingkungan MA hanya ada satu perempuan dan sembilan laki-laki.

Begitupun pada tahun 1999, perempuan yang berhasil sampai di lembaga perwakilan hanya $9 \%^{1}$. Dan sekalipun Megawati telah terpilih untuk memimpin negara ini, ternyata masih banyak menimbulkan kontroversi. Pihak yang tidak setuju menganggap dari sudut budaya sulit menerima perempuan menjadi pemimpin bagi lakilaki. Sedangkan pihak yang bersimpati menyatakan bahwa

\footnotetext{
${ }^{1}$ BPS tahun 2003
} 
peristiwa politik itu menandakan tingginya kesadaran bangsa ini dalam memaknai kesadaran gender, terlepas apakah kualitas perempuan politik terangkat setelah terpilihnya Megawati.

Pemilu 2004 mengamanatkan pencalonan perempuan di Legislatif mencapai 30\%. Namun prakteknya jauh panggang dari api, perempuan yang berhasil sampai di lembaga perwakilan hanya $11,09 \% .^{2}$ Hal ini disebabkan oleh sistem pemilu yang menganut proporsional terbatas hingga menyebabkan suara diberikan pada calon legislatif yang berada pada nomor urut yang paling atas. Kenyatannya banyak Parpol yang mengakali perempuan, sekedar menempatkan banyak perempuan dalam daftar calon, bahkan ada yang lebih 30\% namun ditaruh pada nomor urut sepatu. Padahal keterwakilan perempuan di parlemen sangat penting dan memiliki peran strategis. Dan puncaknya, muncul wacana keharaman perempuan menjadi presiden. Dan ketika beberapa waktu lalu Jawa Timur menggelar pemilihan gubernur, kembali mencuat isu keharaman tersebut. Ini merupakan simbol diskriminasi terhadap perempuan di ranah politik dan itu berarti demokrasi yang senyawa dengan Islam tersebut menjadi terpasung.

\section{B. Politik dan Kepemimpinan Perempuan}

Perempuan mempunyai hak untuk menikmati hak-hak politik, memiliki kesempatan yang sama dengan laki-laki untuk memilih dan dipilih menjadi pemimpin publik dan menduduki jabatan politik. Namun demikian pada pilpres 5 Juli 2004 yang lalu banyak kalangan berdebat tentang kepemimpinan perempuan. Sebagaimana yang dilansir di berbagai media, banyak kalangan yang merasa perlu untuk. Forum Bahsul Masail ikatan pondok se-Jawa Timur yang digelar di PP Roudlotul Ulum Pasuruan mengharamkan perempuan menjadi presiden, sekalipun sudah lama masalah ini menjadi kontroversi, namun selalu saja diusung ketika akan menjelang pemilu ataupun pilkada.

Dalam masyarakat patriarkhi, kepemimpinan memang selalu diidentikkan dengan laki-laki, perempuan tidak berhak menjabat sebagai pemimpin apalagi menjadi presiden, sebuah kepemimpinan tertinggi di sebuah negara. Sebenarnya

\footnotetext{
${ }^{2}$ Ibid
} 
efektivitas pemimpin bukan ditentukan oleh jenis kelamin apa yang sedang berkuasa, tetapi sangat ditentukan oleh kualitas dan perilaku dari pemimpin itu sendiri. Pada hakikatnya esensi dari kepemimpinan nasional terletak pada moral, kualitas dan kapabilitas serta keberpihakannya terhadap rakyatnya.

Kepemimpinan menurut Roach merupakan proses mempengaruhi kelompok kearah pencapaian tujuan yang ditetapkan ${ }^{3}$, oleh sebab itu keberadaan seorang pemimpin merupakan hal yang sangat mutlak diperlukan dalam suatu organisasi, baik di pemerintah maupun swasta, organisasi profit maupun non profit. Kesuksesan suatu organisasi akan sangat ditentukan pada peranan pemimpin dalam mengelola sumber daya organisasi secara optimal dan dapat menjalin relasi yang baik dan berkualitas dengan semua kalangan, tidak peduli laki-laki ataupun perempuan.

\section{Pandangan Islam terhadap Kepemimpinan Perempuan}

Hak-hak perempuan seringkali mendapat hambatan dan tekanan dari berbagai pihak yang masih terpengaruh budaya patriarkhi. Sebenarnya, Islam telah memberi hak-hak pada perempuan, antara lain hak-hak reproduksi, hak-hak politik, sosial, ekonomi, pendidikan, dan bahkan budaya. Namun pada tataran sosial, hak-hak tersebut acap kali disamarkan dengan dalih agama, padahal sebenarnya merupakan hasil penafsiran yang eksistensinya tidak terlepas dari kondisi dan situasi yang yang melingkupi para penafsir, misalnya tentang pelarangan perempuan berkiprah di ranah publik. Hal ini berawal dari pemahaman terhadap teks al-Quran berikut ${ }^{4}$ :

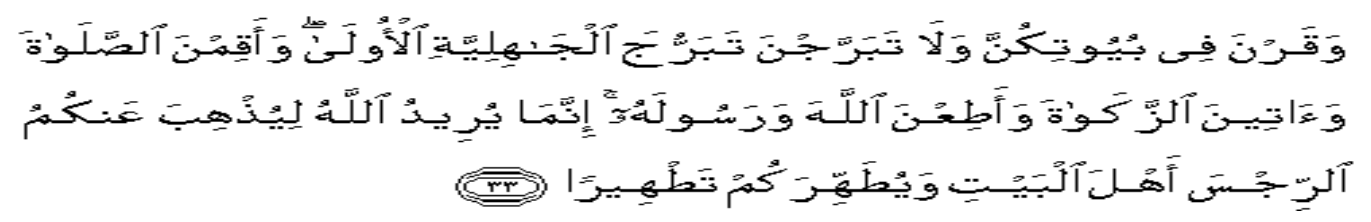

Artinya : Dan hendaklah kamu tetap di rumahmu dan janganlah kamu berhias dan bertingkah laku seperti orang-orang Jahiliyah yang dahulu dan Dirikanlah shalat, tunaikanlah zakat dan taatilah Allah dan RasulNya. Sesungguhnya Allah bermaksud hendak menghilangkan dosa dari kamu, Hai ahlul bait dan membersihkan kamu sebersih-bersihnya.

\footnotetext{
${ }^{3}$ Roach and Behling, 1984

${ }^{4}$ QS. Al-Ahzab,33:33
} 
Teks tersebut dipahami bahwa perempuan harus tinggal di rumah, tidak boleh bekerja di luar rumah. Padahal, makna yg terkandung adalah perempuan harus berada di lingkungan rumah tangganya, bukan rumahtangga orang lain sebagaimana prilaku jahiliyah (ghibah, pamer, pertukaran istri,dan perilaku jelek lainnya), kalau keluar rumah untuk tujuan yg baik seperti bekerja, urusan sosial maka diperbolehkan.

Istri Nabipun banyak yg berperan di ranah publik, seperti Siti Aisyah dan Siti Khodijah. Dan untuk memahami teks tersebut hendaknya juga dikaitkan hadits yang setema, misalnya hadits diizinkannya perempuan keluar rumah baik ke masijid ataupun keperluan yang lain ${ }^{5}$.

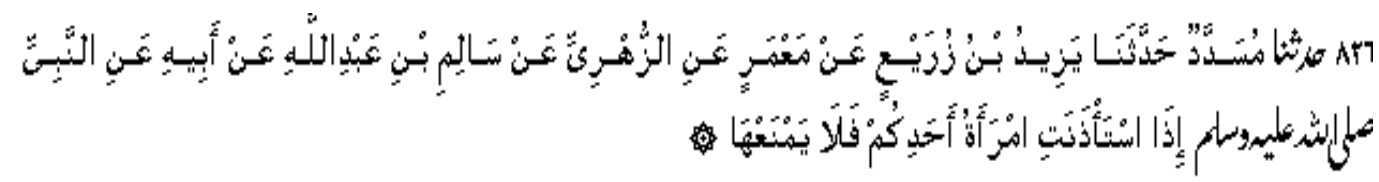

Artinya : Apabila seorang perempuan meminta izin maka janganlah dicegah.

Begitupun soal jabatan hakim, Imam Syafi'i, Maliki, dan Hanbali menolak keabsahan perempuan dalam jabatan ini di semua kategori hukum, baik perdata maupun pidana. Hanafi dan Ibnu Hazm membatasi hanya pada bidang perdata. Ibnu Jarir al-Tobari membolehkan perempuan menjadi hakim dalam segala urusan, dan pendapat ini ditolak oleh al-Mawardi. ${ }^{6}$ Hak publik lainnya yang sering mendapat hambatan adalah kepemimpinan perempuan dalam pemerintahan, baik Presiden, Gubernur, Bupati, Camat, dan lurah. al-Mawardi menegaskan bahwa eksistensi pemerintahan diperlukan untuk melindungi agama dan pengaturan dunia. ${ }^{7}$

Islam agama yang menjunjung tinggi kemanusiaan, yang mengajarkan kedamaian, kasih sayang, persamaan, kesetaraan, dan keadilan. Salah satu bukti dari ajaran tersebut adalah adanya konsep al-kulliyat al-Khamsah atau al-

\footnotetext{
${ }^{5}$ HR Bukhari

${ }^{6}$ Al-Mawardi, al-Ahkamu al-Sulthaniyah, Dar al-Fikri, hal 65

${ }^{7}$ Ibid, hal.3.
} 
daruriyat al-khamsah yang meliputi hifdu al-din, hifdu al-nafs, hifdu al-mal, hifdu al-aql, hifdu al-nasl. Implikasinya, setiap ummat Islam berkewajiban memberikan perlindungan terhadap kelima hak dasar tersebut tanpa membedakan golongan, ras, etnis dan bahkan jenis kelamin.

Misi Islam antara lain membebaskan manusia baik laki maupun perempuan dari belenggu ketertindasan, keterbelakangan, dan ketidakadilan. Banyak teks al-Quran atau hadits yang memproklamirkan hal tersebut. Akan tetapi dalam memahaminya, seringkali mengarah pada pemahaman yang bias gender, seakan-akan teks-teks tersebut mengunggulkan jenis kelamin tertentu. Tidak jarang, teks agama dipahami secara parsial, sehingga terjadi distorsi penafsiran yang seolah-olah agama melakukan diskriminasi terhadap jenis kelamin tertentu.

Wahbah alzuhaili mengungkapkan bahwa laki-laki sebagai syarat menjadi pemimpin adalah merupakan ijma' ulama ahli Fiqih. Hal tersebut didasarkan pada respon Nabi ketika mendengar bahwa masyarakat Persia memilih putri Kisra sebagai pemimpin negara, yang kemudian Nabi bersabda ${ }^{8}$ :

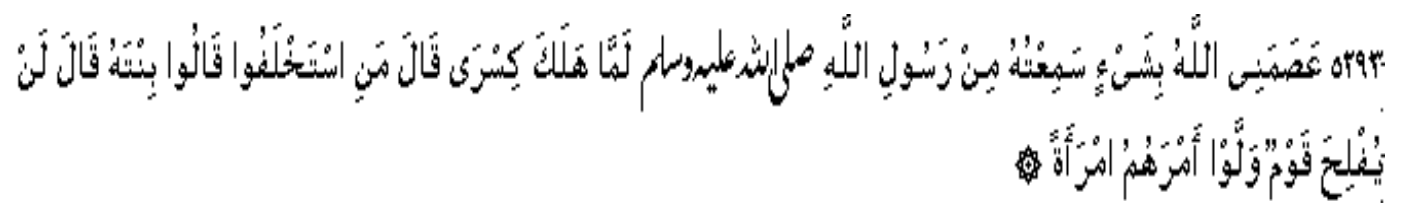

artinya : Tidak akan bahagia suatu kaum jika dipimpin oleh perempuan.

Hadis tersebut dipahami sebagai isyarat bahwa perempuan tidak boleh menjadi pemimpin dalam urusan politik atau pemerintahan. Oleh sebab itu banyak ulama berpandangan bahwa perempuan tidak syah menjadi presiden. Mereka menanggapi hadis ini sebagai syariat yang bersifat baku universal, tanpa melihat aspek-aspek yang terkait dengan Hadits, seperti kapasitas diri Nabi ketika mengucapkan Hadits, dan suasana atau kondisi yang melatar belakangi munculnya Hadits, serta setting sosial yang melingkupi sebuah hadits. Padahal aspek-aspek yang terkait dengan diri Nabi dan kondisi yang melatar belakangi

\footnotetext{
${ }^{8}$ HR an-Nasa'i
} 
munculnya hadits tersebut mempunyai kedudukan penting dalam pemahaman hadits.

\section{Analisis Sanad dan Matan Hadits}

Dari kutipan hadits yang menjadi dasar penolakan kepemimpinan perempuan tersebut, dapat diketahui bahwa urutan periwayatan hadits dari jalur Bukhori adalah Usman bin al-Haisam, al-Hasan, Auf, Abu Bakrah. Adapun dari jalur Ahmad ibn Hanbal adalah Aswad bin Amir, Himad bin Salmah, al-Hasan, Abu Bakrah. Kedua hadis tersebut bertemu pada al-Hasan yang bersumber dari Abu Bakrah.

Fatimah Mernissi menilai bahwa Abu Bakrah adalah mantan budak dan mempunyai reputasi negative terutama semenjak Rasulullah meninggal. Mernissi meragukan hadis ini mengapa hadis itu baru popular setelah muncul masalah politik yang berkaitan dengan Aisyah dan Ali, ternyata Abu Bakrah ada di pihak Ali, jadi wajar jika ia sangat tidak mendukung Aisyah. Kalaupun hadis ini benar maka pernyataan Rasulullah itu hanya tanggapan spontanitas terhadap raja Kisra di Persia yang mewariskan pada anak perempuannya yang belum siap dan tidak mempunyai kapasitas dan kapabilitas.

Berbeda dengan penilaian Mernissi, kualitas perawi hadits tersebut di atas menurut penilaian beberapa ahli hadits adalah menempati peringkat yang tinggi, seperti tsiqah, laba'sa bihi, dan salih hadits. Gelar-gelar tersebut bernilai tinggi dalam hal kualitas pribadi (keadilan) dan intelektual (kedabitan perawi). Seperti halnya Usman bin al-Haisam dinilai tsiqah, sedang Auf oleh Ahmad bin Hanbal dinilai tsiqah, ia tsiqah sabat menurut al-Nasa'i dan katsirulhadits menurut penilaian Ibn Saad. Adapun Aswad bin Amir dinilai soduk salih laba'sa bihi, salih hadits. Sedangkan Himad bin Salmah oleh al-Nasa'i juga dinilai tsiqah. Begitu pula Hamid, al-Hasan dan Abu Bakrah mempunyai kualitas tsiqah.

Adapun mata rantai sanad pada dua jalur adalah ittisal atau bersambung. Bersambungnya sanad tersebut dapat dilihat adanya indikator lafadz yang menggunakan haddasana, 'an, dan juga dilihat dari kemungkinan bertemunya para perawi $\left(\right.$ liqa $\left.^{\prime}\right)$ yang dapat dilacak dari masa hidup dan tempat domisili para perawi yang tercermin dalam nisbatul makan. Dengan demikian dapat 
disimpulkan bahwa hadits tentang larangan perempuan menjadi pemimpin dalam hal ini presiden memiliki sanad sahih atau setidaknya ittisal sanad.

Namun demikian dalam memahami hadis tersebut perlu dicermati dulu keadaan yang sedang berkembang pada saat hadis itu disabdakan, harus dilihat dulu latar belakang munculnya hadits di samping seting sosial saat itu. Oleh sebab itu dalam memahaminya mutlak diperlukan informasi yang memadai mengenai latar belakang kejadiannya.

Jauh sebelum hadis itu muncul, yakni pada masa awal dakwah Islam, Nabi SAW. pernah mengirim surat kepada para pembesar untuk memeluk Islam, diantaranya adalah raja Kisra Persia. Tetapi raja Kisra menolak dan menghina islam bahkan merobek-robek surat Nabi, selang beberapa lama kerajaan Kisra dilanda kekacauan dan pembunuhan yang pada akhirnya diangkatlah seorang perempuan yang tidak mempunyai kualifikasi yang bernama Buwaran binti Syairawih bin Kisra sebagai ratu Persia pada tahun $9 \mathrm{H}$.

Dari seting sosial dapat dikuak bahwa menurut tradisi yang berlangsung di Persia, jabatan raja harus laki-laki, perempuan dianggap tidak mempunyai kemampuan. Dalam kondisi yang demikian wajar Nabi bersabda seperti yang termaktub dalam hadits tersebut di atas. Bagaimana mungkin akan sukses jika yang menjadi pemimpin adalah orang yang tidak mendapat legitimasi masyarakat luas dan tidak mempunyai kualifikasi sebagai pemimpin.

Dengan demikian hadits tentang pernyataan Nabi tersebut bersifat bayanul waqi' (mengungkap realitas sosial yang dihadapai suatu masyarakat) pada saat hadis itu disabdakan. Itu artinya hadits tersebut tidak terkait dengan wacana persyaratan syari'ah kepala Negara, tetapi hanya informasi mengenai pendapat pribadi Nabi yang kemungkinan Nabi tidak menghendaki pemimpin Persia sukses dan jaya, karena mereka pernah menghina Islam. Jadi memaksakan hadis yang berbentuk ikhbar (berita) ke dalam masalah syariat adalah tindakan yang kurang proporsional.

Kini dalam konteks Indonesia kita harus dapat melihat, perempuan yang bagaimanakah yang akan membawa negeri ini ke dalam kehancuran sebagaimana dalam hadis? Apakah semua perempuan, baik perempuan yang mempunyai kadar 
ketaqwaan yang tinggi dan berkualitas, atau hanya perempuan yang tidak mempunyai keahlian dan ketakwaan sebagaimama ratu Kisra dalam hadits tersebut di atas?

Kalau dipikir secara jernih dan tidak emosional serta gegabah, lebih memilih mana antara perempuan yang lebih bertaqwa dan berkompeten, dibanding dengan laki-laki yang tidak lebih baik kadar ketaqwaan dan kapabilitasnya? lebih cenderung mana antara laki-laki dengan perempuan tersebut yang akan membawa kehancuran sebuah Negara? Tentu harus memilih perempuan. Begitu pula sebaliknya akan memilih mana antara laki-laki yang berkompeten dibanding dengan perempuan yang tidak berkompeten? Tentu akan memilih laki-laki yang berkompeten.

Sebagai perempuan, tentu tidak akan membabi buta memilih pemimpin asalkan perempuan, karena ada pemimpin yang secara biologis adalah berjenis kelamin perempuan tetapi secara idiologis tidak perempuan, artinya sekalipun dia perempuan tetapi tidak peka perempuan apalagi rakyat kecil, maka sangat tidak pantas untuk memilih perempuan tersebut menjadi pemimpin. Bukankah kriteria Rosulullah tentang pemimpin adalah sebuah keahlian? jika segala urusan diserahkan pada yang bukan ahlinya, tunggunya saja saat kehancurannya, jadi Bukan jenis kelamin laki-laki atau perempuan yang menjadi ukuran, siapapun jika mempunyai keahlian maka dia berhak menjadi pemimpin ${ }^{9}$.

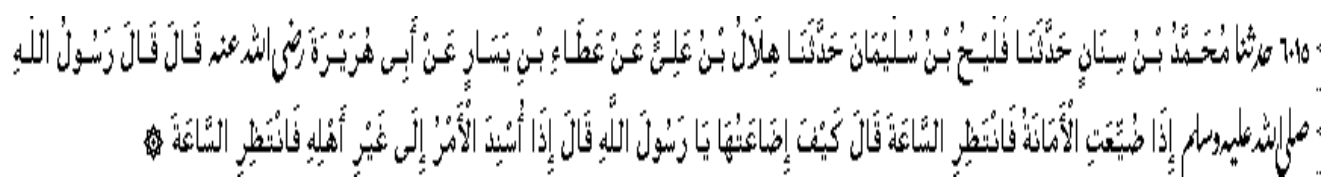

Artinya : Apabila sesuatu urusan diserahkan kepada orang yang bukan ahlinya, maka tunggulah saat keahliannya."

Al-Mawardi ${ }^{10}$ menyatakan bahwa syarat pemimpin adalah adil, mempunyai keahlian/kapasitas keilmuan dan agama, sehat fisik, sehat jasmani rohani, kemampuan memanage untuk maslahatul ummah, keberanian, dan bersih lingkungan. Jelas dari situ tidak nampak adanya syarat bahwa pemimpin harus

\footnotetext{
${ }^{9}$ HR Bukhari

${ }^{10}$ Al-Mawardi,tth:6
} 
laki-laki. Keduanya mempunyai kesempatan yang sama selagi memenuhi syarat yang ditetapkan.

Toha Husen menulis dalam bukunya ${ }^{11}$ bahwa ada tiga prinsip dasar yang dibawa Nabi setelah tauhid, yaitu keadilan (al-adalah), persamaan (almusawamah), dan musyawarah (al-syura). Ketiga prinsip ini juga dibawa oleh khulafau al-rasyidin khususnya Abu Bakar dan Umar. Untuk menegakkan keadilan, mereka tidak membedakan antara si kaya-mikin, Arab-non Arab, lakilaki - perempuan. Mereka juga menekankan adanya persamaan antar sesama manusia. Unsur yang membedakan hanyalah kadar ketaqwaan dan amal shaleh.

Al-Quranpun telah memproklamirkan bahwa Laki-laki dan perempuan sama-sama sebagai hamba Allah, tidak ada perbedaan status atau derajat dalam posisi manusia sebagai hamba (QS.al Dzariyat:51:56). Perempuan memiliki kesempatan dan kemampuan yang sama dengan laki-laki untuk menjadi hamba secara ideal. Dan sebagai hamba Allah, perempuan memiliki kapasitas dan posisi kualitas seorang hamba Allah adalah ketaqwaannya (QS.Al Hujurat: 49: 13).

Laki-laki dan perempuan sama-sama sebagai khalifah (QS. An'am: 6:165), penegasan yang sama dapat ditemukan pada surat al Baqarah (2:30). Fungsi khalifah tidak menunjuk pada salah satu jenis kelamin, atau atribut-atribut manusia yang lain seperti ras, etnis, atau status sosial. Perempuan dan laki-laki memiliki tanggung jawab dan kemampuan yang sama sebagai khalifah. Kedua jenis kelamin juga sama-sama harus mempertanggungjawabkan amalnya di dunia selama menjalankan tugas sebagai khalifah.

Laki-laki dan perempuan berpotensi meraih prestasi sebagai manusia. Dalam al Qur'an terdapat konsep-konsep kesetaraan gender yang bersifat ideal, yaitu pesan yang tegas bahwa prestasi seseorang, baik dalam aktifitas spiritual maupun dalam karier profesional, tidak selalu dimonopoli oleh salah satu jenis kelamin. Islam memberikan kesempatan yang sama bagi laki-laki dan perempuan dalam meraih prestasi secara maksimal. Terdapat empat ayat yang

\footnotetext{
${ }^{11}$ Toha Husien, al-Fitnatu al-Kubro, edisi Indonesia, Kuala Lumpur, Dewan Bahasa dan Pustaka, 1991, hal 9.
} 
mengungkapkan pesan ini yaitu, QS Ali Imran. 3: 195, QS. Al Nisa'. 4: 124, QS. Al Nahl, 16:97, dan QS Gafir, 40:40.

Dengan demikian jika dinilai belum ada perempuan yang mempunyai kadar kualitas yang tinggi maka tentu tidak layak untuk memilih perempuan, tetapi jika dinilai ada perempuan yang berkualitas tinggi dari segi ketaqwaan dan keilmuannya tentu akan lebih bisa membawa negeri ini kearah yang lebih baik.

\section{E. Penutup}

Keterlibatan perempuan di ranah politik merupakan cerminan implementasi dari demokrasi yang diajarkan oleh Islam. Pemberian kesempatan untuk terlibat dalam urusan politik akan memberi manfaat besar bagi terciptanya keadilan dan kesejahteraan bagi semua orang. Kehadiran perempuan diharapkan mampu merumuskan kebijakan-kebijakan negara yang dapat memberdayakan berjuta-juta kaumnya dan menghapus kultur diskriminatif. Persoalannya tinggal bagaimana menciptakan konstruki sosial yang menghargai perempuan terhadap kaum laki-laki dan juga perempuan itu sendiri.

Dalam rangka itulah, harus ada upaya memperbaiki kondisi dan posisi perempuan dalam politik, dengan mengarahkan kembali pada akar permasalahnya, yaitu struktur, kondisi sosial dan kultur masyarakat. Karena kondisi inilah yang memungkinkan terjadinya transformasi sosial bahkan tepatnya menurut Ruwaida adalah "transformasi struktural"12, dari struktural berketidakadilan ke struktur keadilan. Hal ini hanya dimungkinkan dengan berdayanya perempuan baik sebagai indifidu maupun kelompok.

Selanjutnya secara internal berupaya meningkatkan kapasitas dan kualitas diri melalui pendidikan dalam arti luas. Harus ada upaya bersama secara sinergis meningkatkan kualitas diri perempuan dalam bidang politik, sehingga dapat menghindari permainan politik yang tidak eis, kotor dan culas serta tidak manusiawi. Terakhir, perempuan harus berani dan mendorong serta melakukan reinterpretasi ajaran agama sehingga terwujud penafsiran yang akomodatif

${ }^{12}$ Figur, 2008, Aksi Politi Perempuan, Tinjauan Sosiologis Feminis, Edisi XXIV:42 
terhadap nilai-nilai kemanusiaan, penafsiran yang ramah perempuan dan yang pasti rahmatan li al-'alamin. 